\title{
Howard Hughes to shift focus of support away from institutions
}

Washington. The Howard Hughes Medical Institute (HHMI) is to stop funding research at US institutions where HHMIsupported investigators lose their grants or move to different institutions, according to officials at the Maryland-based research organization.

The change in policy will allow the organization to withdraw from the partnerships it has formed with universities when it stops funding particular investigators at these institutions. HHMI views this as a logical step in a strategy that it has been following since 1986 of shifting away from making awards only to investigators at universities with which it is already in partnership, and making them to the best-qualified applicants at any institution.

HHMI, which uses the fortune bequeathed by the late eccentric aviation billionaire Howard Hughes to fund research in molecular biology, is the largest nongovernment supporter of university science in the United States. Last year it spent \$280 million on its investigators, and a further $\$ 50$ million on various grants.

Purnell Choppin, the president of HHMI, said last week that the money that up to now has supported such investigators will revert to a central pool, from where it can be redirected to new investigators anywhere in the United States who are successful in open competition for HHMI awards.

The move will make more HHMI money available for fresh investigators, including choppin: opening funds those at institutions to more investigators. where the institute

has no presence. But the very low level of attrition means it will not lead to a deluge of new grants. Bob Potter, head of communications at HHMI, says the next round of new awards will probably be made in late 1996 or early 1997, adding "ten or twelve" investigators to the current pool of 280. HHMI spends an average of $\$ 1$ million a year supporting each member of this élite group.

Part of the rationale for HHMI's previous policy was a wish to prevent all of its money from following the best researchers into a tiny handful of molecular biology depart$\sum$ ments. But Choppin says that its recent,

I open competitions have not caused this to happen; in 1994, when HHMI made 44 new awards in open competition, it added ten new institutions, and its investigators are now spread across 62 institutions.

Choppin says that HHMI researchers may also get more freedom to change institutions and take HHMI money with them. "At the moment we consider this on a caseby-case basis, and in most cases, they are not free to move," he says. "But we may reconsider that."

Colin Macilwain

\section{Columbia takes over reins at Biosphere 2}

Washington. Columbia University's Lamont-Doherty Earth Observatory at Palisades, New York, is to take over the entire operation of Biosphere 2, the Arizona ecology laboratory built by Texan millionaire Ed Bass, from the beginning of next year, according to officials from the university.

Columbia's take-over of Biosphere 2 completes a period of transition during which Bass ousted the ideologically committed co-founders of the laboratory, and appointed an outside committee of advisers, chaired by Michael McElroy of Harvard University's Earth sciences department, to restore its battered scientific reputation (see Nature 368, 577 \& 370, 495; 1994).

At the end of next month, Biosphere 2's acting chief executive, Stephen Bannon, will be replaced temporarily by Taro Takahasi, an associate director of Lamont-Doherty. A search will then be made for a permanent director, who could be in place by April.

Michael Crow, vice provost of Columbia University, says that up to eight additional groups of scientists would start working at Biosphere 2, and that a small, self-financing college would open there. "There will be a greatly expanded scientific presence, with people from Lamont-Doherty and from other institutions," he says.

Bass has spent an estimated $\$ 150$ million building the huge, hermetically-sealed Biosphere 2 greenhouse in the Arizona desert. The project drew much derision in its early days, when staff tried to survive inside the greenhouse for several months without external support. But it is being increasingly accepted by ecologists and others as a potentially powerful tool for investigating the complex relationship between the earth, the atmosphere and living things. C. $\mathbf{M}$. 